\title{
RESEARCH ON TOURISTS' ATTITUDES ON THE POTENTIAL OF GOČ MOUNTAIN FOR THE DEVELOPMENT OF ECO-TOURISM
}

\author{
Snežana Milićevićl , Nataša Đorđević2 , Živana Krejić3, \\ *Corresponding author E-mail: snezana.milicevic@kg.ac.rs
}

A R T I C L E I N F O
Review Article
Received: 31 October 2019
Accepted: 26 November 2019
doi:10.5937/ekoPolj2001223M
UDC 338.486.41(497.11 Goč)

Keywords:

Goč mountain, ecotourism, eco-accommodation, tourists attitudes

JEL: L83, Z32

\section{A B S T R A C T}

Goč Mountain has a wealth of natural resources, which represent the most important prerequisite for the development of ecotourism. However, the natural resources of this mountain are inadequately utilized for tourism. The aim of the research is to examine the views of tourists on the possibilities for the development of ecotourism on the mountain Goč, with a view to the more intensive tourist development of this mountain. Special attention is paid to the analysis of possibilities for expanding the existing tourist offer, additional attractive contents and activities, which would contribute to the greater competitiveness of this mountain in the ecotourism market. The survey method was used to collect primary data in the research and it included 174 respondents. The results of the descriptive statistical analysis showed that Goč Mountain has the potential for ecotourism development and that the construction of eco-accommodation facilities would contribute to the greater competitiveness of Goč Mountain.

(C) 2020 EA. All rights reserved.

\section{Introduction}

Mountain Goč is located near the leading spa in Serbia, Vrnjačka Banja. The comparative advantage of Goč Mountain is reflected primarily in its natural predispositions. An ecologically preserved environment, characterized by distinct forestedness, natural landscapes and rich flora and fauna, distinguish Mountain Goč as still insufficiently explored and included in tourist flows (Podovac, Đorđević, Milićević, 2018). Owing

1 Snežana Milićević, Associate professor, University of Kragujevac, Faculty of Hotel Management and Tourism in Vrnjačka Banja, Vojvođanska 5A, 36210 Vrnjačka Banja, 036/5150024, snezana. milicevic@kg.ac.rs, ORCID ID (https://orcid.org/0000-0002-1972-9585)

2 Nataša Đorđević, Teaching assistant, University of Kragujevac, Faculty of Hotel Management and Tourism in Vrnjačka Banja, Vojvođanska 5A, 36210 Vrnjačka Banja, 036/5150024, natasa.djordjevic@kg.ac.rs ORCID ID (https://orcid.org/0000-0002-3630-6867)

3 Živana Krejić, Assistant professor, Union University, Faculty of Business Studies and Law, Jurija Gagarina 149a, 11070 Novi Beograd, 066/9007878, zivana.krejic@fpsp.edu.rs, ORCID ID (https://orcid.org/0000-0003-2490-5755) 
to its natural features, first of all biodiversity conservation and forest communities, as well as the beauty of the countryside, favourable climate, richness of rivers and created values, Mountain Goč fully meets the requirements for protection as the Institute for Nature Conservation of Serbia, 2019). The whole area of the Goč Mountain is characterized by tourist potentials with dominant health and sports and recreational character, which unfortunately have not yet been adequately utilized. Existing natural resources should be a significant factor in the intensive tourism development of this mountain, with particular emphasis on the development of ecotourism.

In recent years, tourists have been coming to Goč Mountain in the summer when the main motive is exploring nature, walking through natural areas and relaxing in the clear mountain air. However, the tourist offer of this mountain is not sufficiently developed, and therefore not attractive to potential tourists, which is confirmed by tourist traffic. Mountain Goč recorded an extremely small number of tourists. In 2017, 8,350 tourists visited this mountain, including domestic tourists, who realized 46,265 overnight stays (Statistical Office of the Republic of Serbia, 2019).

Considering the strong impact on the environment and a wide range of positive and negative effects on rural communities, long-term sustainability of agricultural activities must be taken into account (Đokić, 2019). Each rural area has natural and anthropogenic values, which can serve as a basis for creating an attractive tourist product. However, particularly insisted on lately is ecology and sustainable development. Tourists of today want an environmentally friendly environment in which to spend their free time (Vuković, Arsić, Cvijanović, 2010; Milićević, Podovac, Jovanović, 2013). Ecotourism is a form of tourism that emphasizes natural and ecological attractions. This type of tourism aims at "returning to nature", learning about nature and respecting the connection between people and the country. It takes place in undisturbed natural areas and is a form of tourism that seeks to protect the environment, improve the quality of life of the local population, and educate tourists (Milićević, Štetić, 2017).

Many mountain communities around the world have promoted ecotourism ventures to ameliorate problems of environmental degradation and underdevelopment. It is generally believed that this form of tourism in the mountains will foster responsible tourist behavior, conservation of important wildlife habitats and ecosystems, appreciation of local cultures and traditional life styles, and provision of sustainable forms of livelihood for people living in remote areas and communities (Nepal, 2002). Based on the fundamental functions of ecotourism we can say that its success at a destination is reflected by the extent to which it satisfies these key requirements: preserves natural resources and biodiversity; generates money to finance conservation; contributes to the local economy; promotes community partnership; and educates visitors and members of local communities (Batta, 2006).

The aim of the paper is to examine the views of tourists on the possibilities for the development of ecotourism on the mountain Goč, with a view to the more intensive tourist development of this mountain. Special attention is paid to the analysis of 
possibilities for expanding the existing tourist offer, additional attractive contents and activities, which would contribute to the greater competitiveness of this mountain in the ecotourism market. The survey was conducted among tourists of Goč Mountain.

\section{Literature review}

The concept of sustainable development is faced with great interest both in theory, by scientific researchers, and in practice, by managers and policy makers in many countries (Sudarević, Milovanov, 2015). The development of environmental awareness of the threat of the natural environment leads to a new nature of tourism and essential changes in relation to the environment (Šušić, Đorđević, 2019). The term ecotourism has often been equated with a number of terms like alternative tourism, green tourism, sustainable tourism (Butler 1991), or nature tourism, even though these are distinct forms of tourism (Nepal, 2002). The lack of a precise definition of the term ecotourism has encouraged increasing free use of the term to gain competitive advantage (Batta, 2006).

According to Ceballos-Lascuráin (1987), ecotourism is defined as travelling to relatively undisturbed or uncontaminated natural areas with the specific objective of studying, admiring, and enjoying the scenery and its wild plants and animals, as well as any existing cultural manifestations found in these areas. Ecotourism is a form of tourism that fosters learning experiences and appreciation of the natural environment, or some component thereof, within its associated cultural context' (Weaver, 2008). The most important motivations for travel by ecotourists are to enjoy the natural environment, have an "experiential" vacation, and learn while traveling. Typically, the most popular ecotourism activities in all surveys are visiting national parks and protected areas, hiking, waterbased activities (especially rafting), admiring nature, camping and touring. Additionally, cultural experiences may be of interest (Wight, 2001). Activity preferences vary from destination to destination. For example, diving is rated highly in the Pacific, while jungle/ rainforest trekking and birdwatching are rated highly in Latin America and Southeast Asia, and game viewing is popular in Africa (IFC, 2004). Tourists learning is central to all forms of ecotourism (Weaver, Lawton, 2007), and one expressed goal of ecotourism is the self-formation of tourists towards more pro-environmental attitudes and behaviour (Buckley, 2009). Ecotourists are simply interested in natural places and experiences for the benefits of enjoyment and learning, physical activity and adventure (Beaumont, 2011). Recent ecotourism research has found that ecotourism markets prefer more than the conventional hotel options. They desire more rustic, adventure-type accommodation (such as ecolodges, campings, backpacker hostels, ranches, etc.) which is a growing market trend. The overall vacation experience seems to determine the accommodation choice (Wight, 2001).

Achieving ecotourism requires certain activities including the production of ecologically safe, recyclable and biodegradable products, using energy efficient operations with minimal or no pollution, efficient waste management, con-serving cultural and natural assets, etc. (Gavrilović, Maksimović, 2018). According to UNWTO (2019), ecotourism refers to forms of tourism which have the following characteristics: 
1. All nature-based forms of tourism in which the main motivation of the tourists is the observation and appreciation of nature as well as the traditional cultures prevailing in natural areas.

2. It contains educational and interpretation features.

3. It is generally, but not exclusively organised by specialised tour operators for small groups. Service provider partners at the destinations tend to be small locally owned businesses.

4. It minimises negative impacts upon the natural and socio-cultural environment.

5. It supports the maintenance of natural areas which are used as ecotourism attractions by:

- Generating economic benefits for host communities, organisations and authorities managing natural areas with conservation purposes;

- Providing alternative employment and income opportunities for local communities;

- Increasing awareness towards the conservation of natural and cultural assets, both among locals and tourists.

From the above it is clear that ecotourism can be defined by three core criteria: nature, learning and sustainability (Beaumont, 2011), ie, (1) attractions should be predominantly nature based, (2) visitor interactions with those attractions should be focused on learning or education, and (3) experience and product management should follow the principles and practices associated with ecological, socio-cultural and economic sustainability (Blamey, 2001).

Many mountain tourist destinations have become major players in the local economy. Hiking, camping, mountain and rock climbing, mountain biking, wildlife viewing, and other forms of non-consumptive recreation are in growing demand. However, there are dangers in promoting mountain destinations for ecotourism, especially if there is no strategic focus on the type and intensity of activities to be promoted, the benefits and the beneficiaries, and the decisions related to governance, control and regulations. Some of the major environmental impacts with direct implications for local mountain communities include overcrowding, noise pollution, garbage pollution, extraction of valuable resources (for example, collection of firewood and rare plant specimens), fire hazard, and a sewage outflow (Nepal, 2002).

Environmental anxiety about tourism impacts has increased and the accommodation sector in tourism has identified the necessity to improve its sustainable management and process (Trauer, 1998). The development of eco-accommodation is an example of this change to more sustainable tourism accommodations. Eco-accommodations are environmentally friendly establishments where hospitality services are provided to the eco-tourists while practicing ecotourism principles, such as saving water and 
energy as well as reducing solid waste - while saving money - to help protect earth (Manaktola, Jauhari, 2007; Arachchi, Yajid, Khatibi, 2015; Milićević, 2016; Green Hotels Association, 2019). They can be found in nature tourism destinations around the world. There are different types of eco-accommodations: Ecohotels, Ecoresorts, Ecoguesthouses, Ecolodges, Ecoapartments, Ecocampings, Glampings, etc. The primary difference between these eco-accommodations is generally the amount of services that are provided on site. For example, ecoresorts tend to be located on larger properties, and may offer more amenities, such as spas, a choice of restaurants, and/ or a variety of local tours. One thing all of these eco-accommodation options have in common is that they emphasize elements such as environmental responsibility and minimizing the negative impact (Green Global Travel, 2019). Ecotourism is rapidly evolving, so accommodation facilities should use this as a chance to improve their business (Milićević, Petrović, Šuleić, 2017).

Regional nature parks of France have developed specific trade marks for environmentally friendly accommodations - Ecogîtes. The Ecogîtes are part of a way of life based on preserving natural resources, using the renewable energies, the use of natural, local and recyclable material with no harmful effects on health. Ecogites properties have facilities and equipment for saving energy, sorting rubbish and economising water (Gites de France, 2019). These self-catering accommodations provide visitors information about the local fauna and flora, direct access by foot to nature sites, and provide materials intended to increase visitor awareness of the areas visited (Blangy, Vautier, 2001).

An excellent example of ecolodge is Eden Lodge Madagascar, which is several times selected in the Top 10 ecolodges in the World (elected 2014 World's best sustainable lodge). Eden Lodge is also the first Green Globe certified lodge in Madagascar. Eden Lodge co-exists in harmony with the natural environment and wildlife that surrounds it. The area is renowned for its very high rate of endemism that includes Boab trees over 500 year's old, marine turtles, lemurs, birdlife, reptiles and amphibians. The property uses $100 \%$ solar power. Eden Lodge was exclusively built with local natural renewable materials (stone walls, local wood, ravinala roofs) and construction is based on traditional building principles that suit the climate. Eden Lodge is part of a tight knit community and has formed strong relationships with local villagers, many of whom are employed at the Lodge (Eden Lodge, 2019).

\section{Analysis of the tourist offer of the mountain Goč}

Goč is a mountain in central Serbia, located $200 \mathrm{~km}$ from Belgrade. In its immediate surroundings are Vrnjačka Banja $(15 \mathrm{~km})$, Kraljevo $(31 \mathrm{~km})$, Aleksandrovac and Brus $(22 \mathrm{~km})$. It is part of the north-Kopaonik range and belongs to the category of lower mountains. The highest peak of Goč is the Krnja jela, with an altitude of 1,127 m. On the Kraljevo side of the mountain Goč there is a tourist center "Good Water ", on the spa side there are settlements "Horizont" and "Stanišinci", while from the Aleksandrovac side of Goč, i.e. on its southern slope, there is a settlement "Mitrovo Polje" (Goč Mountain, 2019a). 
Due to its geographical location, climatic characteristics, and especially relief and geological background, this area has a versatile plants coverage, which has so far identified about 650 plant species, of which 250 are medicinal species (Institute for nature conservation of Serbia, 2019). Pursuant to the Decree of the Government of the Republic of Serbia, in 2014, the forest complex "Goč-Gvozdac" was proclaimed a Special Nature Reserve of category II. The protected area is $3.957 \mathrm{ha} 17 \mathrm{a} 39 \mathrm{~m}^{2}$. The most common species of trees in the protected natural resource is beech, which accounts for $52.4 \%$ of the total volume. The forest complex consists of 25 species of trees, some of which are under a special regime of protection (maple, Pančić's spruce- placed, Turkish hazel (a relic), black rake (a relic), wild cherry, wild apple, etc.) (Faculty of Forestry Belgrade, 2019a).

In the area 129 bird species have been recorded, of which 108 are breeding birds. A large number of these birds are of particular national importance. According to the Decree on the Protection of Natural Rarities of Serbia, 75 bird species have been recorded so far as natural rarities. The presence of 317 species of insects was also recorded, of which 56 species are rare and endangered at national and international levels. 27 species of mammals have been identified in the wider Goč area. Certainly of the highest value is the otter (Lutra lutra), which is protected by law as a natural rarity. This species is an indicator of water pollution (Institute for nature conservation of Serbia, 2019). There are also 20 species of amphibians and reptiles (Faculty of Forestry Belgrade, 2019a). In the forest area of the mountain Goč, there are different kinds of game: deer, roe deer, wild boar, rabbit, wolf, fox and others.

This whole area is extremely rich in water resources. It has numerous springs and clear mountain rivers flowing towards the West Morava River in the north and the Rasina River in the south. The hydrographic network also includes the artificial reservoir Selište, built on the river Zagrža, which covers an area of about 8 ha (Rsovac, 2008). Swimming and fishing are prohibited on the artificial lake, as well as any other activities because Vrnjačka Banja is supplied with water from this lake.

Goč also has cultural and historical monuments, the most interesting of which is the "Roman Cemetery", that is, the place where the Saxons, miners who mined and smelt iron during the period of the Nemanjić were buried (National Tourism Organization of Serbia, 2019). There are a couple of sacral objects on the territory of Goč Mountain and the foothills: the Church of the Blessed Virgin Mary in Stanišinci and the Church of St. John in Vukošica, which is unique because it belongs to the type of smallest chalet churches in Serbia (Borović Dimić, 2008). The entire surroundings of Goč Mountain abound in medieval monasteries (Studenica, Ljubostinja, Žiča, etc.) and the remains of medieval cities and fortifications (Ras, Maglič, Koznik, etc.).

Ethnographic values exist, but are not sufficiently valorised. They are found in the gastronomic offer, which is characterized by cheese, kajmak and brandy from Goč, as well as raspberry and blackberry products. A special experience is the trout ponds, where visitors can enjoy a meal and an unspoiled nature on site (Milićević, Đorđević, 2015). 
When it comes to the receptive elements necessary for the development of tourism on the Goč Mountain, it must be said that they are underdeveloped. The existing accommodation on Mount Goč is modest. The accommodation offer includes primarily holiday homes ("Kaćunak", "Goč", "Gočka kuća"), mountain houses ("Goč", "Pecić", "Radulović"), apartments ("Horizont", "Velja", "Djurovski”, "Nikola and Barbara") and a villa ("Slavica"). From Kraljevo side of Goč there is a resort "Good Water", as well as two ethno log cabins (Podovac, Đorđević, Milicević, 2018). The Center for Teaching and Scientific Facilities of the Faculty of Forestry in Belgrade is located in this settlement, which has five accommodation facilities: "Novi Studenac", "Piramida", "Villa Vlasta", "Villa Planinka" and "Depadans". Fieldwork for students of the Faculty of Forestry in Belgrade is organized in them, as well as for students of other faculties in Serbia. The facilities offer accommodation for individual tourists as well as organized groups (Faculty of Forestry Belgrade, 2019b). To the list of accommodation, facilities should be added the resorts in Mitrovsko Polje, on the Aleksandrovac side of Goč, namely the "Red Cross" resort from Aleksandrovac and the "Cvetna dolina" resort belonging to the Ministry of Internal Affairs of the Republic of Serbia (Ministry of Internal Affairs of the Republic of Serbia, 2019). A great problem on the Goč mountain is the cottages that are being built without a permit, which initiates communal problems, but also affects the disturbance of natural landscapes (Milićević, Đorđević, 2015). Goč Mountain provides numerous opportunities for improving the existing accommodation offer, through the construction of various eco-accommodation capacities, which would be in harmony with the natural environment.

When it comes to sports, recreational and entertainment facilities, several locations on Mount Goč have outdoor sports grounds for basketball, handball, volleyball, football and tennis. Within the children's resort "Good Water" (Dobre vode in Serbian), there are several outdoor sports fields, as well as a sports balloon hall of $1000 \mathrm{~m}^{2}$, which contains three volleyball courts, handball (mini football), basketball, tennis court and gym. The natural beauties of Goč Mountain combined with these sports facilities are ideal for the preparation of athletes of all types and categories (Resort Goč, 2019a). There are also small sports fields, three sand volleyball courts and an outdoor pool in Mitrovo Polje. The pool is with thermomineral water in Mitrovo Polje (Mitar's Field), which operates within the Red Cross resort of Aleksandrovac (Mitrovo Polje, 2019).

Goč Mountain also has several marked recreational walking trails, which give tourists and one-day visitors the opportunity to take long walks and pleasant aromatherapy while picking the various plants and teas that this mountain abounds in. More and more tourists and one-day visitors come to Goč in the summer when the main motive is walking and resting in the clear mountain air. For this purpose, 5 walking trails have been established and marked from Kraljevo side of the Goč Mountain. The trails are of different lengths (from 5,000 $\mathrm{m}$ to $18,500 \mathrm{~m}$ ) and different ascent (from 100 meters to 700 meters) and are marked with different colours: yellow, green, brown, blue and red (Resort Goč, 2019b). From Aleksandrovac side of Mount Goč, there are marked hiking trails that lead to the top of Mount Željin and Ljukten (one of the peaks on Mount Goč). 
After hiking on the slopes of Goč Mountain and the surrounding mountains, tourists can relax in the open-air swimming pool with thermo-mineral water in Mitrovo Polje, which operates within the Red Cross Resort in Aleksandrovac (Mitrovo Polje, 2019).

Goč has mountaineering associations operating in its area, namely the mountaineering sports association Ljukten from Trstenik and the mountaineering association Goč from Vrnjačka Banja. These associations also deal with the marking of walking trails, and thanks to them, most of the mountain is marked and facilitates movement for visitors to the mountain (Goč Mountain, 2019b).

In addition to the walking paths, Goč offers five excursion points and four lookout points. The checkpoints are used for holidaying tourists in the countryside and picnics, that is, the possibility for preparing and consuming food. The viewpoint offers a unique view of Vrnjačka Banja, the West Morava valley and the surrounding mountains: Kopaonik, Željin and the Gledić Mountains (Ruđinčanin, 2008).

\section{Research methodology and hypothesis}

The subject of this paper deals with the analysis of the potential of the Goč Mountain for the development of ecotourism, which would have the effect of increasing the number of tourists, i.e. the competitiveness of this mountain in the ecotourism market. The survey method was used to collect primary data in the research. The survey was conducted during July and August of 2019 on Goč Mountain. The survey was preceded by the preparation of a questionnaire consisting of 10 closed-ended questions. The questionnaire was divided into two parts. The first part of the questionnaire deals with the socio-demographic profile of tourists: gender of respondents, age and level of education. In the second part of the questionnaire, the respondents gave an assessment of the existing tourism offer of Goč Mountain, as well as answered questions related to the potential of this mountain for the development of ecotourism, with special emphasis on additional contents that would contribute to the faster development of this type of tourism. The questionnaire was completed by 174 respondents, that is, tourists of the Goč Mountain. The obtained data were processed by Statistical Package for Social Sciences Version 23 - SPSS.

Descriptive statistical analysis was used in the paper. The basic hypotheses on which the research is based are the following:

\section{H1 - Goč Mountain has the potential to develop ecotourism}

H2 - Eco-accommodation facilities would contribute to greater competitiveness of mountain Goč in the ecotourism market.

The main objective of the conducted research is to examine the possibilities for the development of ecotourism on the mountain Goč. Special attention was paid to the analysis of possibilities for expanding the existing tourist offer through the construction of eco-accommodation capacities, all with the aim of increasing the competitiveness of this mountain in the ecotourism market. 


\section{Results and discussion}

The survey included 174 respondents, of whom 98 were female $(56.3 \%)$ and 76 were male (43.7\%). The largest number of respondents is $36-50$ years old (33.3\%), followed by 26-35 years old respondents (28.7\%). Regarding the level of education, the most represented are respondents with university education (50.6\%), while the least are those with a high school degree (14.9\%). When asked Have you ever been to Goč Mountain, as many as 173 respondents answered positively (99.4\%), while only 1 respondent $(0.6 \%)$ had never been to Goč (Table 1$)$.

Table 1. Socio-demographic characteristics of respondents

\begin{tabular}{|c|c|c|c|c|c|}
\hline & & Frequency & Percent & Mean & Std. dev. \\
\hline \multirow{2}{*}{ Gender } & Male & 76 & 43,7 & \multirow{2}{*}{1,56} & \multirow{2}{*}{,497 } \\
\hline & Female & 98 & 56,3 & & \\
\hline \multirow{4}{*}{ Age } & $20-25$ & 31 & 17,8 & \multirow{4}{*}{2,56} & \multirow{4}{*}{1,006} \\
\hline & $26-35$ & 50 & 28,7 & & \\
\hline & $36-50$ & 58 & 33,3 & & \\
\hline & More than 50 & 35 & 20,1 & & \\
\hline \multirow{4}{*}{ Level of education } & High school & 28 & 16,1 & & \\
\hline & College & 26 & 14,9 & \multirow{3}{*}{2,71} & \multirow{3}{*}{,948 } \\
\hline & University degree & 88 & 50,6 & & \\
\hline & Master/Magistar/PhD & 32 & 18,4 & & \\
\hline \multirow{2}{*}{$\begin{array}{l}\text { Have you ever been } \\
\text { to Goč Mountain }\end{array}$} & Yes & 173 & 99,4 & \multirow{2}{*}{1,01} & \multirow{2}{*}{0,76} \\
\hline & No & 1 & 0,6 & & \\
\hline
\end{tabular}

Source: Authors, based on research

When asked for an Assessment of the current state of certain elements of Goč Mountain tourism offer, the respondents gave a rating on the Likert scale, ranging from 1 (the worst rating) to 5 (the best rating). After analyzing the responses shown in Table 2 , it is evident that the average ratings of individual elements of the tourist offer of this mountain range from 3.47 to 4.58 . The highest average marks were given by the following elements of the tourist offer: The natural beauties of Goč Mountain (4.58), the tidiness and cleanliness of Goč Mountain (4.51), as well as The conservation of rural areas and rural architecture (4.30). Tourists are the most satisfied with the natural resources of Goč Mountains, which is a good basis for the development of eco-tourism. On the other hand, the worst rated elements are Local Tourist Signalling (3.47) and Traffic Access (3.51). With an average mark of 3.72, the tourists rated Accommodation facilities on this mountain, indicating that there is a need to improve the quality of existing tourist accommodation facilities, but also to introduce new, attractive accommodation facilities, which would increase the level of tourist satisfaction. 
Table 2. Tourists' satisfaction with certain elements of Goč mountain tourist offer

\begin{tabular}{|c|l|c|c|c|r|}
\hline & & $\begin{array}{c}\text { Min } \\
\text { mark }\end{array}$ & $\begin{array}{c}\text { Max } \\
\text { mark }\end{array}$ & Mean & $\begin{array}{c}\text { Std. } \\
\text { dev. }\end{array}$ \\
\hline 1 & The natural beauties of Goč mountain & 2.00 & 5.00 & 4,58 &, 777 \\
\hline 2 & The arrangement and cleanliness of mountain Goč & 2.00 & 5.00 & 4,51 &, 788 \\
\hline 3 & Preservation of rural area and rural architecture & 2.00 & 5.00 & 4,30 &, 773 \\
\hline 4 & Cultural and historical heritage & 2.00 & 5.00 & 4,21 &, 681 \\
\hline 5 & Places for picnic and camping & 1.00 & 5.00 & 4,11 &, 788 \\
\hline 6 & The offer of the restaurants & 2.00 & 5.00 & 4,10 &, 732 \\
\hline 7 & Sports and recreational offer & 1.00 & 5.00 & 3,81 &, 821 \\
\hline 8 & Accommodation facilities & 1.00 & 5.00 & 3,72 &, 778 \\
\hline 9 & Traffic accessibility & 1.00 & 5.00 & 3,51 &, 854 \\
\hline 10 & Local tourist signage & 1.00 & 5.00 & 3,47 &, 687 \\
\hline
\end{tabular}

Source: Authors, based on the research

To the next question, Has Mount Goč got the potential to develop ecotourism?, as many as 169 respondents $(97.1 \%)$ answered affirmatively, while only $5(2.9 \%)$ answered in the negatively (Table 3 ).

Table 3. Has Mount Goč got the potential to develop ecotourism?

\begin{tabular}{|c|c|r|r|r|r|r|r|}
\hline \multicolumn{2}{|c|}{} & Frequency & Percent & $\begin{array}{c}\text { Valid } \\
\text { percent }\end{array}$ & $\begin{array}{c}\text { Cumulative } \\
\text { percent }\end{array}$ & Mean & $\begin{array}{c}\text { Std. } \\
\text { dev. }\end{array}$ \\
\hline \multirow{3}{*}{ Valid } & Yes & 169 & 97,1 & 97,1 & 97,1 & & \\
\cline { 2 - 8 } & No & 5 & 2,9 & 2,9 & 100,0 & 1,03 &, 168 \\
\cline { 2 - 9 } & Total & 174 & 100,0 & 100,0 & & & \\
\hline
\end{tabular}

Source: Authors, based on research

Next, the respondents were asked What additional facilities and activities would contribute to the development of ecotourism on Mount Goč? For this question 10 answers were and the possibility for respondents to opt for only one answer (Table 4). The largest number of respondents opted for Horseback riding opportunities, as well as for the Marked mountain biking trails (30 respondents each, i.e. 17.2\% each). For better-marked hiking trails, 29 respondents (16.7\%) opted, while 26 respondents (14.9\%) opted for Eco-accommodation facilities. The answers for which the least respondents opted were Picking Mushrooms and herbs accompanied by local guides and Eco-workshops (5 respondents, i.e. 2.9\% respondents). It can be concluded that all the answers offered to tourists are interesting and that the mentioned additional facilities and activities would contribute to the faster development of eco tourism on the mountain Goč. 
Table 4. What additional facilities and activities would contribute to the development of ecotourism on Goč?

\begin{tabular}{|l|c|c|c|c|}
\hline \multicolumn{1}{|c|}{ Answers } & Frequency & Percent & $\begin{array}{c}\text { Valid } \\
\text { percent }\end{array}$ & $\begin{array}{c}\text { Cumulative } \\
\text { percent }\end{array}$ \\
\hline Horseback riding opportunities & 30 & 17,2 & 17,2 & 17,2 \\
\hline Marked trails for mountain biking & 30 & 17,2 & 17,2 & 34,5 \\
\hline Better marked trails for recreational hiking & 29 & 16,7 & 16,7 & 51,1 \\
\hline Eco-Accommodation facilities & 26 & 14,9 & 14,9 & 66,1 \\
\hline $\begin{array}{l}\text { Additional recreational and entertainment offer: Zip } \\
\text { line, Adventure park, Paragliding, Cable car from } \\
\text { Vrnjačka Banja to Goč }\end{array}$ & 24 & 13,8 & 13,8 & 79,9 \\
\hline More marked hiking trails & 13 & 7,5 & 7,5 & 87,4 \\
\hline $\begin{array}{l}\text { Cultural manifestations on the traditions and customs } \\
\text { of the local population }\end{array}$ & 6 & 3,4 & 3,4 & 90,8 \\
\hline Bird watching & 6 & 3,4 & 3,4 & 94,3 \\
\hline $\begin{array}{l}\text { Picking mushrooms and herbs accompanied by local } \\
\text { guides }\end{array}$ & 5 & 2,9 & 2,9 & 97,1 \\
\hline Eco-workshops & 5 & 2,9 & 2,9 & 100,0 \\
\hline \multicolumn{1}{|c|}{ Total } & 174 & 100 & & \\
\hline
\end{tabular}

Source: Authors, based on the research

Since less environmentally harmful accommodation facilities that bring human beings closer to nature can be an important element in the supply of an eco-destination, survey questions regarding eco-accommodation facilities are defined. To the question Have you ever been housed in an eco-accommodation facility (Eco camping, Eco apartments, Eco lodge, Eco hotel, Glamping)?, more than half (52.3\%) said they had used this type of accommodation, while $47.7 \%$ did not (Table 5).

Table 5. Have you ever been housed in an eco-accommodation facility?

\begin{tabular}{|c|c|r|r|r|r|r|r|}
\hline \multicolumn{2}{|c|}{} & \multicolumn{1}{|c|}{ Frequency } & Percent & $\begin{array}{c}\text { Valid } \\
\text { percent }\end{array}$ & $\begin{array}{c}\text { Cumulative } \\
\text { percent }\end{array}$ & Mean & Std. dev. \\
\hline \multirow{3}{*}{ Valid } & Yes & 91 & 52,3 & 52,3 & 52,3 & & \\
\cline { 2 - 8 } & No & 83 & 47,7 & 47,7 & 100,0 & 1,48 &, 501 \\
\cline { 2 - 8 } & Total & 174 & 100,0 & 100,0 & & & \\
\hline
\end{tabular}

Source: Authors, based on research

Respondents were also asked What kind of eco-accommodation facilities would you like Goč to offer?. For this question 6 answers were offered and the possibility for respondents to opt for only one answer. The largest number of respondents opted for Eco hotel (33.3\%), while 21.8\% of respondents opted for Eco apartments (Table 6). This is followed by Eco Lodge (20.1\%), Eco Camping (19.5\%), as well as Glamping, with $5.2 \%$ of respondents. It is interesting that none of the respondents opted for the sixth offered answers that reads None of the offered ones - Mountain Goč does not need this type of accommodation. Such answers indicate the great environmental awareness of the respondents, and the desire to contribute in this way to the protection of the environment of Goč Mountain. 
Table 6. What kind of eco-accommodation facilities would you like Goč to offer?

\begin{tabular}{|l|c|c|c|c|}
\hline \multicolumn{1}{|c|}{ Answers } & Frequency & Percent & Valid percent & Cumulative percent \\
\hline Eco hotel & 58 & 33,3 & 33,3 & 33,3 \\
\hline Eco apartments & 38 & 21,8 & 21,8 & 55,2 \\
\hline Eco lodge & 35 & 20,1 & 20,1 & 75,3 \\
\hline Eco camping & 34 & 19,5 & 19,5 & 94,8 \\
\hline Glamping & 9 & 5,2 & 5,2 & 100,0 \\
\hline \multicolumn{1}{|c|}{ Total } & 174 & 100 & 100 & \\
\hline
\end{tabular}

Source: Authors, based on research

The last question referred to the respondents' position on Would eco-accommodation facilities affect the arrival of more tourists to Goč Mountain?. As many as $97.1 \%$ of respondents answered affirmatively, while $2.9 \%$ said that eco-accommodations would not affect the arrival of more tourists to this mountain (Table 7).

Table 7. Would eco-accommodation facilities affect the arrival of more tourists to Goč Mountain?

\begin{tabular}{|c|c|r|r|r|r|}
\hline \multicolumn{2}{|c|}{ Answers } & \multicolumn{1}{c|}{ Frequency } & \multicolumn{1}{c|}{ Percent } & \multicolumn{1}{c|}{$\begin{array}{c}\text { Valid } \\
\text { percent }\end{array}$} & $\begin{array}{c}\text { Cumulative } \\
\text { percent }\end{array}$ \\
\hline \multirow{3}{*}{ Valid } & Yes & 169 & 97,1 & 97,1 & 97,1 \\
\cline { 2 - 6 } & No & 5 & 2,9 & 2,9 & 100,0 \\
\cline { 2 - 6 } & Total & 174 & 100,0 & 100,0 & \\
\hline
\end{tabular}

Source: Authors, based on research

\section{Conclusions}

In this paper, two hypotheses were set. The accuracy of both hypotheses was verified using descriptive statistical analysis. The first hypothesis that reads Goč Mountain has the potential for the development of ecotourism, is considered to be confirmed given that as many as 169 respondents (97.1\%) gave a positive answer to this question. In addition, the respondents were given the opportunity to choose among the 10 offered answers one additional content or activity that they felt would be most conducive to the development of eco-tourism on Goč Mountain. Based on the respondents' answers, it can be concluded that these additional facilities and activities would indeed contribute to the faster development of eco-tourism on Goč Mountain, given that all the answers offered to the respondents were interesting. However, the contents opted by the largest number of respondents are: Horseback riding opportunities (17.2\%), Marked mountain biking trails (17.2\%), Better marked hiking trails (16.7\%), Eco- accommodation facilities (14.9\%), as well as additional recreational and entertainment offer (Zip line, Adventure park, Paragliding, Cable car from Vrnjačka Banja to Goč, etc.) (13.8\%).

The second hypothesis is Eco-accommodation facilities would contribute to the increased competitiveness of Goč Mountain in the ecotourism market was also confirmed by the respondents' answers. Specifically, 169 respondents (97.1\%) confirmed that the ecoaccommodation facilities would affect the arrival of more tourists to Goč Mountain. 
The fact that more than half of the surveyed respondents $(52.3 \%)$ were already housed in one of the eco-accommodation facilities is in favour of confirming the hypothesis, which suggests that they would use this type of accommodation on Goč Mountain in the future. In addition, when asked about the type of eco-accommodation facilities that tourists would like Goč to have in their offer, the respondents showed interest in all the eco-accommodation facilities offered: Eco hotel (33.3\%), Eco apartments (21.8\%), Eco lodge (20.1\%), Eco camping (19.5\%) and Glamping (5.2\%), with the important note that none of the respondents indicated that Goč Mountain does not need such type of accommodation. Since there is obviously an interest of tourists for eco-accommodation facilities, and given that they do not exist on this mountain, in the future it is necessary to direct business activities to enrich the existing accommodation offer by building attractive eco-accommodation facilities. All this would contribute to faster development of ecotourism as well as greater competitiveness of Mount Goč in the eco-tourism market.

\section{Acknowledgements}

Paper is a part of research within the project no. III 46006 - Sustainable agriculture and rural development in the function of accomplishing strategic objectives of the Republic of Serbia in the Danube region, financed by the Ministry of Education, Science and Technological Development of the Republic of Serbia.

\section{Conflict of interests}

The authors declare no conflict of interest.

\section{References}

1. Arachchi, R. S. S. W., Yajid, M. S. A., \& Khatibi, A. (2015). Ecotourism practices in Sri Lankan eco resorts: A supplier perspective analysis. Journal of Tourism and Hospitality Management, 3(9-10), 169-180. DOI: 10.17265/2328-2169/2015.10.001

2. Batta, R. N. (2006). Evaluating ecotourism in mountain areas: A study of three Himalayan destinations. International Review for Environmental Strategies, 6(1), 41-62.

3. Beaumont, N. (2011). The third criterion of ecotourism: Are ecotourists more concerned about sustainability than other tourists?. Journal of Ecotourism, 10(2), 135-148. DOI: 10.1080/14724049.2011.555554.

4. Blamey, R. K. (2001). Principles of ecotourism. The encyclopedia of ecotourism, 2001, 5-22.

5. Blangy, S., \& Vautier, S. (2001). Europe. In D. B. Weaver(Ed.), The Encyclopedia of Ecotourism (pp. 155-171), Oxon, UK, CAB International. 
6. Borović Dimić, J. (2008). Cultural and historical heritage of Vrnjačka Banja, in: B. Ruđinčanin \& O. Topalović (Eds), Vrnjačka Banja at the beginning of the 21st century (pp. 79-82). Vrnjačka Banja, National Library Dr Dušan Radić. [in Serbian: Borović Dimić, J. (2008). Kulturno-istorijsko nasleđe Vrnjačke Banje, u: B. Ruđinčanin \& O. Topalović (Ured.), Vrnjačka Banja na početku 21. veka (str. 79-82). Vrnjačka Banja, Narodna biblioteka dr Dušan Radić].

7. Buckley, R. C. (2009). Evaluating the net effects of ecotourism on the environment: A framework, first assessment and future research. Journal of Sustainable Tourism, 17(6), 643-672. DOI:10.1080/09669580902999188

8. Butler, R. W. (1991). Tourism, environment and sustainable development. Environment Conservation, 18(3), 201-209. DOI: 10.1017/S0376892900022104

9. Ceballos-Lascuráin, H. (1987). The future of ecotourism. Mexico Journal, 1, 13-14.

10. Eden Lodge (2019). Responsible tourism, Retrived from http://edenlodge.net/en/ hotel-madagascar/responsible-tourism (Jun 03, 2019).

11. Faculty of Forestry Belgrade (2019a). Special nature reserve Goč-Gvozdac, Retrived from http://www.sfb.bg.ac.rs/nastavne-baze/nastavna-baza-goc/ specijalni-rezervat-prirode-goc-gvozdac/ (August 25, 2019).

12. Faculty of Forestry Belgrade (2019b). Accommodation capacity, Retrived from http://www.sfb.bg.ac.rs/nastavne-baze/nastavna-baza-goc/smestajni-kapacitet/ (Jun 25, 2019).

13. Gavrilović, Z., \& Maksimović, M. (2018). Green innovations in the tourism sector. Strategic Management, 23(1), 36-42.

14. Gites de France (2019). Ecogites, Retrived from https://www.gites-de-france.com/ en/our-holidays-in (August 27, 2019).

15. Goč mountain (2019a). Retrived from https://www.goc.rs/goc (July 10, 2019).

16. Goč mountain (2019b). Retrived from http://vbanja.com/planina-goc/ (July 15, 2019).

17. Green Hotels Association (2019). Why should hotels be green?, Retrived from http://greenhotels.com/index.php (August 03, 2019).

18. Green Global Travel (2019). Eco Resort, Eco Lodge, or Eco Hotel?, Retrived from https://greenglobaltravel.com/eco-lodges-eco-resorts-eco-hotels/\#What $\% 20 \mathrm{Is} \% 20$ An\%20Eco\%20Lodge? (August 20, 2019).

19. Đokić, M. (2019). Sustainable Agricultural and Rural Development in The European Union. Economics of Sustainable Development, 3(1), 29-43.

20. IFC (2004). Ecolodges: exploring opportunities for sustainable business, Retrived from https://www.academia.edu/10715712/Ecolodges_Exploring_Opportunities_ for_Sustainable_Business(July 05, 2019). 
21. Manaktola, K., \& Jauhari, V. (2007). Exploring consumer attitude and behavior towards green practices in the lodging industry in India. International. Journal of Contemporary Hospitality Management, 19(5), 364-377. DOI: 10.1108/09596110710757534

22. Milićević, S., \& Đorđević, N. (2015). Potentials for development of mountain Goč as destination of rural tourism. Ekonomija teorija i praksa, 8(4), 86-97. [in Serbian: Milićević, S., \& Đorđević, N. (2015). Potencijali za razvoj planine Goč kao destinacije ruralnog turizma].

23. Milićević, S. (2016). Innovation in the function of growth and development of tourism industry in tourism market. Megatrend revija, 13(1), 147-158. [in Serbian: Milićević, S. (2016). Inovativnost u funkciji rasta i razvoja turističke industrije na turističkom tržištu].

24. Milićević, S., Petrović, J., \& Šuleić, J. (2017). Eco-innovation in tourism and hospitality in function improvement of competitiveness on tourism market, $X I$ International Scientific Conference "Innovations in Hospitality and Tourism", HORES, Belgrade, 16.-18.11.2017, Zlatibor, pp. 68-77.

25. Institute for nature conservation of Serbia (2019). Goč-Gvozdac, Retrived from http://www.zzps.rs/novo/index.php?jezik=sr\&strana=zastita_prirode_osrp_goc (July 25, 2019).

26. Milićević, S., Podovac, M., \& Jovanović, D. (2013). Sustainable tourism development with special reference to the European Union. Hotel and Tourism Management, 1(1), 21-30.

27. Milićević, S., \& Štetić, S. (2017). Menadžment u turizmu, University of Kragujevac, Faculty of Hotel Management and Tourism in Vrnjačka Banja.

28. Ministry of Interior of the Republic of Serbia (2019), Food and Accommodation Directorate, Retrived from http://arhiva.mup.gov.rs/cms_lat/sfljrzp.nsf/uprava-zaposlove-ishrane-i-smestaja.h (July 03, 2019).

29. Mitrovo Polje (2019). Retrived from https://www.goc.rs/mitrovo-polje (July 15, 2019).

30. National Tourism Organization of Serbia (2019). Goč mountain, Retrived from http://www.srbija.travel/destinations/cities-and-municipalities.a-5.692.html (July 15, 2019).

31. Nepal, S. K. (2002). Mountain ecotourism and sustainable development: Ecology, economics and ethics. Mountain Research and Development, 22(2), 104-109. DOI: 10.1659/0276-4741(2002)022[0104:MEASD]2.0.CO;2

32. Podovac, M., Đorđević, N., \& Milićević, S. (2019). Rural tourism in the function of life quality improvement of rural population on Goč mountain. Economics of Agriculture, 66(1), 205-220. DOI: 10.5937/ekoPolj1901205P

33. Resort Goč (2019a). Sports preparations, Retrived from http://odmaralistegoc.rs/ sr/proizvodi/sportske-pripreme (August 23, 2019). 
34. Resort Goč (2019b). Recreational trails on Goč, Retrived from https:// odmaralistegoc.rs/sr/proizvodi/rekreativne-staze-na-gocu (August 20, 2019).

35. Rsovac, B. (2008). Hydrographic characteristics, in: B. Ruđinčanin \& O. Topalović (Eds), Vrnjačka Banja at the beginning of the 21st century (pp. 79-82). Vrnjačka Banja, National Library Dr Dušan Radić. [in Serbian: Rsovac, B. (2008). Hidrografske karakteristike, u: B. Ruđinčanin \& O. Topalović (Ured.), Vrnjačka Banja na početku 21. veka (str. 79-82). Vrnjačka Banja, Narodna biblioteka dr Dušan Radić].

36. Ruđinčanin, B. (2008). Tourism, in: B. Ruđinčanin \& O. Topalović (Eds), Vrnjačka Banja at the beginning of the 21 st century (pp. 321-333). Vrnjačka Banja, National Library Dr Dušan Radić [in Serbian: Ruđinčanin, B. (2008). Turizam, u: B. Ruđinčanin \& O. Topalović (Ured.), Vrnjačka Banja na početku 21. Veka (str. 321333). Vrnjačka Banja, Narodna biblioteka dr Dušan Radić].

37. Statistical Office of the Republic of Serbia (2019). Statistical Yearbook of Serbia 2018, Retrived from http://publikacije.stat.gov.rs/G2018/Pdf/G20182051.pdf (March 20, 2019).

38. Sudarević, T., \& Milovanov, O., (2015). The Synergistic Action of the Main Actors in the Field of Sustainable Production and Consumption. Annals of the Faculty of Economics in Subotica, 51(34), 15-28.

39. Šušić, V., \& Đorđević, D. Ž. (2019). Modern tendencies of international tourism development. Ekonomika, 65(2), 27-37.

40. Trauer, B. (1998). Green tourism in the hotel and resort sector: International and New Zealand perspectives. Australian Parks and Leisure, 1(2), 5-9.

41. UNWTO (2019). Ecotourism and Protected areas, Retrived from https://sdt.unwto. org/content/ecotourism-and-protected-areas (July 10, 2019).

42. Vuković, P., Arsić, S., \& Cvijanović, D. (2010). Competitiveness of a rural tourist destinations. Economics of Agriculture, 57(1), 47-60. [in Serbian: Vuković, P., Arsić, S., \& Cvijanović, D. (2010). Konkurentnost ruralnih turističkih destinacija].

43. Weaver, D. B., \& Lawton, L. (2007). Progress in tourism management. Twenty years on: The state of contemporary ecotourism research. Tourism Management, 28(1), 1168-1179. DOI:10.1016/j.tourman.2007.03.004.

44. Weaver, D. B. (2008). Ecotourism. Australia, Milton, Qld John Wiley \& Sons.

45. Wight, P. A. (2001). Ecotourists: Not a Homogeneous Market Segment, in D. B. Weaver (Ed.), The Encyclopedia of Ecotourism (pp. 37-62), Oxon, UK, CAB International. 